\section{Riociguat in systemic sclerosis: a potential for disease modification}

We read with great interest the results of the recently published Riociguat Safety and Efficacy in Systemic Sclerosis (RISE-SSc) trial $^{1}$ and believe that additional analyses could further elucidate the role of riociguat in systemic sclerosis (SSc).

First, considering the pleiotropic (antifibrotic, antiinflammatory and antiproliferative) actions of riociguat, an analysis of the radiographic findings [pattern- cellular non-specific interstitial pneumonia (NSIP), fibrotic NSIP or usual interstitial pneumonia (UIP); and the extent of fibrosis) in the subset of patients with interstitial lung disease (ILD) could provide useful preliminary information regarding the subset of SSc-ILD most likely be benefited with riociguat and the dominant mechanism behind its potential efficacy.

Second, what was the change in forced vital capacity (FVC) in millilitre in the two groups? As done in the Safety and Efficacy of Nintedanib in Systemic Sclerosis (SENSCIS) trial in SSc-ILD, studying absolute change in millilitre, rather than percentage predicted FVC, could help avoid masking early signals of efficacy. ${ }^{2}$

Third, a post hoc analysis of the effect of riociguat on swollen joints (31.4\% patients), tender joints (42.1\% patients), tenosynovitis and serum levels of $\mathrm{C}$ reactive protein could provide valuable evidence regarding the contribution of anti-inflammatory action $^{3}$ to its overall efficacy.

With an already proven efficacy in SSc-pulmonary hypertension $^{4}$ and early signals of efficacy in skin tightening, ILD and prevention of digital ulceration, riociguat holds promise as a potential disease-modifying agent in the diverse manifestations of SSc. Trials in SSc-ILD, and those employing the exploratory and post hoc endpoints of RISE-SSc as primary outcomes, are much needed.

\section{Siddharth Jain, Varun Dhir 우}

Division of Clinical Immunology and Rheumatology, Department of Internal Medicine, Post Graduate Institute of Medical Education and Research, Chandigarh, India
Correspondence to Dr Varun Dhir, Clinical Immunology and Rheumatology, Department of Internal Medicine, Post Graduate Institute of Medical Education and Research, Chandigarh 160012, India; varundhir@gmail.com

Contributors SJ drafted the manuscript. VD critically reviewed it. Both authors approved the final version of the submitted manuscript.

Funding The authors have not declared a specific grant for this research from any funding agency in the public, commercial or not-for-profit sectors.

Competing interests None declared.

Patient and public involvement Patients and/or the public were not involved in the design, or conduct, or reporting, or dissemination plans of this research.

Patient consent for publication Not required.

Provenance and peer review Not commissioned; internally peer reviewed.

(C) Author(s) (or their employer(s)) 2020. No commercial re-use. See rights and permissions. Published by BMJ.

Check for updates

To cite Jain S, Dhir V. Ann Rheum Dis Epub ahead of print: [please include Day Month Year]. doi:10.1136/annrheumdis-2020-218180

Received 1 June 2020

Accepted 2 June 2020

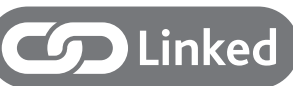

http://dx.doi.org/10.1136/annrheumdis-2020-218194

Ann Rheum Dis 2020;0:1. doi:10.1136/annrheumdis-2020-218180

ORCID iD

Varun Dhir http://orcid.org/0000-0002-3626-0694

\section{REFERENCES}

1 Khanna D, Allanore $Y$, Denton $C P$, et al. Riociguat in patients with early diffuse cutaneous systemic sclerosis (RISE-SSc): randomised, double-blind, placebo-controlled multicentre trial. Ann Rheum Dis 2020;79:618-25.

2 Distler $\mathrm{O}$, Highland KB, Gahlemann M, et al. Nintedanib for systemic sclerosisassociated interstitial lung disease. N Eng/ J Med 2019;380:2518-28.

3 Ahluwalia A, Foster P, Scotland RS, et al. Antiinflammatory activity of soluble guanylate cyclase: cGMP-dependent down-regulation of P-selectin expression and leukocyte recruitment. Proc Natl Acad Sci U S A 2004;101:1386-91.

4 Humbert M, Coghlan JG, Ghofrani H-A, et al. Riociguat for the treatment of pulmonary arterial hypertension associated with connective tissue disease: results from PATENT-1 and PATENT-2. Ann Rheum Dis 2017;76:422-6. 